\title{
Do People Pay More Attention to Earthquakes in Western Countries?
}

\author{
Habibi, Hanna ${ }^{a}$ and Feld, Jan ${ }^{b}$

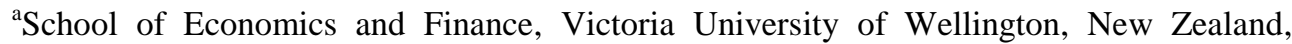 \\ ${ }^{\mathrm{b}}$ School of Economics and Finance, Victoria University of Wellington, New Zealand.
}

\begin{abstract}
This paper investigates whether people from Western countries pay more attention to earthquakes in Western countries than those in non-Western countries. Using Google Trends data, we examine the proportion of Google searches from the United States, the United Kingdom, Canada, Australia, and New Zealand for 610 earthquakes across the world over the period of 2006-2016. Our results suggest that people in these countries pay around 44 percent more attention to earthquakes in Western countries, holding constant earthquake magnitude and number of casualties. Our results remain significant and similar in magnitude after controlling for geographical and social characteristics, but reduce in magnitude to almost zero and become insignificant after controlling for GDP per capita of the countries where the earthquake struck. Our results suggest that there is a developed country bias, rather than a Western country bias, in people's attention. This bias might lead to a lower flow of international relief to economically less developed countries, which are less able to deal with disasters.
\end{abstract}

Keywords: Public attention, natural disasters, internet search volume 


\section{Introduction}

Public attention to critical events is important because it leads to action from non-profit organisations and governments (Newig, 2004; Newell, 2006). For example, the rise in media attention to the issue of climate change during 2006-2007 led to a considerable increase in national-level climate legislations in 2007-2008 (Schmidt et al., 2013). Yet, we know little about what generates public attention. There is anecdotal evidence that people from Western countries pay more attention to critical events in Western countries. Take, for example, natural disasters that hit a country unexpectedly. Franks (2006) compares the media coverage of Hurricane Katerina in the United States and Hurricane Stanley in Guatemala that struck within weeks from each other in 2005. By the end of January 2006, the newspapers in the United Kingdom referred to Hurricane Katerina 3,105 times, while there were only 34 mentions of Hurricane Stanley. However, this comparison only relies on two natural disasters and furthermore, Frank looks at media coverage and not directly at public attention. Media coverage might have other drivers. We do not know whether people are biased towards natural disasters in Western countries as well.

In this paper, we test whether people from Western countries pay more attention to earthquakes in Western countries holding constant earthquake characteristics such as, the magnitude of the earthquake, the number of deaths, and whether the earthquake generated a tsunami. We measure public attention to 610 significant earthquakes across the world from 2006-2016, using the proportion of Google searches on the keyword "earthquake + country name" from internet users in the United States, the United Kingdom, Canada, Australia, and New Zealand. We broadly follow Samuel Huntington (1993) and categorize Western countries as Western Europe, the United States, Canada, Australia, and New Zealand. ${ }^{1}$

A number of studies have investigated the determinants of media attention to natural disasters (Eisensee and Strömberg, 2007; Van Belle, 2000; Koopmans and Vliegenthart, 2010). Koopmans and Vliegenthart (2010) who have the most similar variables to our study, investigate the determinants of media attention from the United States, the United Kingdom and the Netherlands and find insignificant results for the earthquakes in Western countries. While these studies focus on media attention, we use Google Trends to measure public attention directly. Factors such as the limited number of reporters in the country of the earthquake might have an influence on the media attention to such earthquakes but, nowadays, the events that grab people's attention are not limited to those that are covered in the media. In sum, we are the first to examine explicitly whether people, as opposed to the media, in Western countries pay more attention to earthquakes that strike in Western countries than those in non-Western countries.

\footnotetext{
${ }^{1}$ Beside these countries, Huntington recognizes Papua New Guinea and French Guiana as Western countries. We have decided to exclude them because they are not generally considered as Western countries.
} 


\section{Data and Empirical Strategy}

\subsection{Data}

We obtain our data on earthquakes from the Global Significant Earthquake Database provided by National Oceanic and Atmospheric Administration (National Geophysical Data Center, 2017). ${ }^{2}$ In our analysis, we control for earthquake characteristics including magnitude, death toll, and whether the earthquake generated a tsunami. Table (1) shows summary statistics for our estimation sample.

Table 1. Descriptive Statistics

\begin{tabular}{lccccc}
\hline & $(1)$ & $(2)$ & $(3)$ & $(4)$ & $(5)$ \\
& N & Mean & SD & Min & Max \\
\hline Public Attention & 2,950 & 1.42 & 8.38 & 0 & 100 \\
Western & 2,950 & 0.15 & 0.36 & 0 & 1 \\
Magnitude & 2,950 & 5.98 & 1.09 & 1.60 & 9.10 \\
Tsunami & 2,950 & 0.20 & 0.40 & 0 & 1 \\
Number of Deaths & 2,950 & 728.3 & 13,490 & 0 & 316,000 \\
Distance (in 10,000 kms) & 2,950 & 0.994 & 0.424 & 0.019 & 1.959 \\
Common Border & 2,950 & 0.02 & 0.12 & 0 & 1 \\
Share of Migrants in the Country of Earthquake & 2,950 & 0.25 & 0.44 & 0 & 5.75 \\
Colony & 2,950 & 0.07 & 0.25 & 0 & 1 \\
Share of Christians & 2,950 & 0.43 & 0.41 & 0.00 & 0.99 \\
Common Official First Language & 2,950 & 0.29 & 0.45 & 0 & 1 \\
GDP per capita (in 10,000s USD) & 2,950 & 1.224 & 1.572 & 0 & 6.221 \\
\hline
\end{tabular}

NOTE. - All numbers are based on our estimation sample. 'SD' refers to the standard deviation of the respective variable.

We use monthly Google Trends data to measure public attention. Google Trends is an analytical tool that provides data on the proportion of Google searches on a particular topic, reflecting Google users' interest in that topic. This analytical tool allows for comparison between different topics adjusting for time and location. It takes a random sample of Google search data as representative of all Google searches and provides a proportionate measure, scaled from 0-100, that shows the amount of Google searches on a particular topic in a given time and location. This scaling means that Google Trends data adjusts for differences in the number of internet users in different locations (Google, 2017). We collect the data for Google searches from the United States, the United Kingdom, Canada,

\footnotetext{
${ }^{2}$ This database contains information on earthquakes that meet at least one of the following criteria; 10 or more deaths, approximately 1 million USD or more damage, a magnitude of 7.5 on the Richter scale or greater, the Modified Mercalli Intensity (MMI) of X or greater ${ }^{2}$, or whether the earthquake generated a tsunami.
} 
Australia, and New Zealand on the search term "earthquake + country name" in the month in which the earthquake occurred. ${ }^{3}$ We measure attention by exploring Google Trends data for "earthquake + country name" and adjusting the search for geolocation and time period of interest. We obtain the monthly Google Trends score of our keywords for the period 2006-2016 from specific origin of search - limited to the five countries that we measure their attention -, one at a time. Since Google Trends allows for the comparison between different keywords, we compare the keywords for all the earthquakes to identify the earthquake that received the highest amount of attention in the sample period in a given country. For example, Google users in the United States paid the highest attention to "Earthquake Japan" in March of 2011, and for this reason, its Google Trends score is 100. Following this approach, we obtain the data on the proportion of Google searches on our 610 earthquakes of interest from the mentioned five countries for the period of 2006-2016. As shown in table (1), the mean of public attention equals 1.42 percent. The skewed distribution and considerably low mean are the result of the fact that people pay so much attention to a few earthquakes while many earthquakes barely receive any attention.

Our explanatory variable of interest is a Western dummy. Relying broadly on Huntington (1993), we categorize Western countries as countries in Western Europe, the United States, Canada, Australia, and New Zealand. Almost 15\% of earthquakes in our database struck in Western countries.

We categorize our control variables into three categories, geographical, social, and economic characteristics. Geographical characteristics includes the distance in kilometres and whether the countries are neighbour. The data on these two variables is available on GeoDist database (CEPII, 2017). Social characteristics include common official first language, colony, share of migrants, and share of Christians. The data on common official first language and colonial ties is also available on the GeoDist database (CEPII, 2017). We use the data on bilateral migration from the World Bank (Özden et al., 2011) to measure the share of migrants from the country of the earthquake in the country where we measure public attention. Finally, we obtain the data on the share of Christians in the countries where the earthquake struck in 2015 from the World Christian Database (Johnson and Zurlo, 2007). Lastly, we use GDP per capita in USD as our measure of economic characteristics and obtain the data on countries GDP per capita from the World Bank.

\footnotetext{
${ }^{3}$ Google is by far the most popular search engine in the world as well as the five countries that we measure their public attention. Google captured almost $87 \%, 90 \%, 94 \%, 95 \%$, and $91 \%$ of the market share of search engine users in the United States, the United Kingdom, Australia, New Zealand, and Canada respectively in 2017. This share on average is almost 17 times higher than the share of second popular search engine (Bing) in these countries (Stats, 2017).
} 


\subsection{Empirical Strategy}

In order to understand the role of Western country status in the public attention paid to earthquakes, we estimate four specifications using the following empirical model:

$$
\operatorname{Ln}\left(\text { Attention }_{i c}\right)=\beta_{1} \text { Western }_{i}+\delta X_{i c}^{\prime}+u_{i c}
$$

where $\operatorname{Ln}\left(\right.$ Attention $\left._{i c}\right)$ is the natural logarithm of the Google Trends score for earthquake $i$ in country $c$ (country of attention) which is our measure of public attention. Because we have many values between zero and one, we add one to the Google Trends score and take its log. Western $n_{i}$ is a dummy variable that is equal to one if the earthquake struck in a Western country. The coefficient of interest is $\beta_{1}$ which shows the increase in public attention when the earthquake occurred in a Western country. To allow for the number of deaths and the magnitude of the earthquake to have non-linear effects on attention, we include cubic polynomials of magnitude and the number of deaths. In all specifications, we control for these earthquake characteristics. We also include country of attention fixed effects, and to account for countries paying more attention to earthquakes in their own country we include a domestic dummy. Because we observe the attention to the same earthquake from five countries, we cluster standard errors at the earthquake level.

The vector $X_{i c}^{\prime}$ contains our three sets of control variables, geographical, social, and economic characteristics that we include in some of our specifications. Geographical characteristics contains bilateral distance and neighbour - a dummy variable equalling one when the two countries are contiguous. Social characteristics contains four control variables: share of migrants that is the share of migrants from the country of earthquake in country of attention, share of Christians in the country of the earthquake, a dummy for whether the country of earthquake and country of attention had colonial ties, and a dummy if the two countries share an official first language. Our measure of economic characteristics is GDP per capita of the country of earthquake for each year.

\section{Results}

Table 2 shows how Western country status predicts public attention in the United States, the United Kingdom, Canada, Australia, and New Zealand. We find that people in these countries pay more attention to earthquakes in Western countries. Our results suggest that earthquakes in Western countries receive 0.37 log points - about 44 percent - more public attention than earthquakes in non-Western countries with the same magnitude and number of casualties. This result stays consistent after additionally controlling for geographical and social characteristics (columns 1, 2, and 3). However, after controlling for economic characteristics we get insignificant results for Western country status (column 4). Results of 
this specification suggest that a 10,000 USD increase in GDP per capita increases the public attention to earthquakes by $0.15 \log$ point - around 16 percent. The Western bias seems to be driven by people paying more attention to earthquakes in economically developed countries. The results of our last specification are consistent with Koopmans and Vliegenthart (2010) who found insignificant results for Western country status when controlling for GDP per capita.

Table 2. Determinants of Public Attention to Earthquakes

\begin{tabular}{|c|c|c|c|c|}
\hline Dependent Variable: & $\begin{array}{c}(1) \\
\text { Log Public } \\
\text { Attention }\end{array}$ & $\begin{array}{c}(2) \\
\text { Log Public } \\
\text { Attention }\end{array}$ & $\begin{array}{c}(3) \\
\text { Log Public } \\
\text { Attention }\end{array}$ & $\begin{array}{c}(4) \\
\text { Log Public } \\
\text { Attention }\end{array}$ \\
\hline Western & $\begin{array}{c}0.365 * * * \\
(0.083)\end{array}$ & $\begin{array}{c}0.376 * * * \\
(0.085)\end{array}$ & $\begin{array}{c}0.454 * * * \\
(0.083)\end{array}$ & $\begin{array}{c}0.024 \\
(0.146)\end{array}$ \\
\hline Distance (in 10,000 kms) & & $\begin{array}{c}-0.140 * * \\
(0.021)\end{array}$ & $\begin{array}{c}-0.127 * * \\
(0.022)\end{array}$ & $\begin{array}{c}-0.125 * * \\
(0.021)\end{array}$ \\
\hline Neighbour & & $\begin{array}{l}-0.055 \\
(0.096)\end{array}$ & $\begin{array}{l}-0.166 \\
(0.112)\end{array}$ & $\begin{array}{c}-0.350 * * \\
(0.119)\end{array}$ \\
\hline Colony & & & $\begin{array}{l}-0.075 \\
(0.032)\end{array}$ & $\begin{array}{l}-0.092 \\
(0.034)\end{array}$ \\
\hline Common Official First Language & & & $\begin{array}{c}-0.136 * * * \\
(0.041)\end{array}$ & $\begin{array}{c}-0.089 * * \\
(0.039)\end{array}$ \\
\hline Share of Migrants from Country of Earthquake & & & $\begin{array}{c}0.167 * * * \\
(0.043)\end{array}$ & $\begin{array}{c}0.160 * * * \\
(0.049)\end{array}$ \\
\hline Share of Christians & & & $\begin{array}{c}-0.189 * * * \\
(0.070)\end{array}$ & $\begin{array}{c}-0.187 * * * \\
(0.058)\end{array}$ \\
\hline GDP per capita (in 10,000 s USD) & & & & $\begin{array}{c}0.146^{* * *} \\
(0.041)\end{array}$ \\
\hline Earthquake Characteristics & YES & YES & YES & YES \\
\hline R-squared & 0.277 & 0.284 & 0.320 & 0.381 \\
\hline Observations & 2,950 & 2,950 & 2,950 & 2,950 \\
\hline
\end{tabular}

NOTE. - The dependent variables in all Columns are the log of public attention, which is a proportionate measure scaled from 0-100 calculated by Google Trends. All columns are estimated with OLS regressions that include country-of-attention fixed effect, magnitude of the earthquakes, number of deaths and a dummy variable, which is equal to 1 if the earthquake generated tsunami. We include cubic polynomials of magnitude and number of deaths to control for their non-linear effects. The regressions also include a dummy variable, which is equal to 1 if the earthquake is stricken in the same country that attention is captured from. Robust standard errors in parentheses are clustered at earthquake level. * $\mathrm{p}<0.1,{ }^{*} \mathrm{p}<0.05, * * * \mathrm{p}<0.01$. 


\section{Conclusion}

We have estimated the role of Western country status on the public attention paid to 610 earthquakes across the world from 2006 to 2016. Our findings show that people from the United States, the United Kingdom, Canada, Australia, and New Zealand pay on average 50 percent more attention to earthquakes in Western countries than to earthquakes in nonWestern countries. This result disappears after controlling for GDP per capita of the country in which an earthquake struck, suggesting that the bias in attention is mainly towards more economically developed countries rather than Western countries. A potential consequence of this bias is that it may make it difficult to motivate governments to provide relief for less developed countries who may need the help more urgently.

\section{References}

Balla, S. J., Lodge, M. \& Page, E. C. (Eds.). (2015). The Oxford handbook of classics in public policy and administration. OUP Oxford.

CEPII - Centre d'Études Prospectives et d'Informations Internationales (2017) GeoDist database. [Online]. Available: http://www.cepii.fr/anglaisgraph/bdd/distances.htm [Accessed: 2017 September].

Eisensee, T., \& Strömberg, D. (2007). News droughts, news floods, and US disaster relief. The Quarterly Journal of Economics, 122(2), 693-728.

Franks, S. (2006). The CARMA report: western media coverage of humanitarian disasters. The Political Quarterly, 77(2), 281-284.

Global Bilateral Migration Database, World Bank Group Özden, Ç., Parsons, C. R., Schiff, M. \& Walmsley, T. L. (2011). Where on earth is everybody? The evolution of global bilateral migration 1960-2000. The World Bank Economic Review, 25(1), 12-56.

Google (2017) Google Trends. [Online]. Available: http://www.google.com/trends/. [Accessed 2017 June]

Huntington, S. P. (1997). The clash of civilizations and the remaking of world order. Penguin Books India.

Johnson, T. M. \& Zurlo, G. A. (2007). World christian database. Leiden/Boston: Brill.

Koopmans, R. \& Vliegenthart, R. (2010). Media attention as the outcome of a diffusion process-A theoretical framework and cross-national evidence on earthquake coverage. European Sociological Review, 27(5), 636-653.

National Geophysical Data Center / World Data Service (NGDC/WDS): Global Significant Earthquake Database. National Geophysical Data Center, NOAA. doi:10.7289/V5TD9V7K [Accessed 2017 June]

Newell, P. (2006). Climate for change: Non-state actors and the global politics of the greenhouse. Cambridge University Press.

Newig, J. (2004). Public attention, political action: the example of environmental regulation. Rationality and Society, 16(2), 149-190. 
Özden, Ç., Parsons, C. R., Schiff, M. \& Walmsley, T. L. (2011). Where on earth is everybody? The evolution of global bilateral migration 1960-2000. The World Bank Economic Review, 25(1), 12-56.

Schmidt, A., Ivanova, A. \& Schäfer, M. S. (2013). Media attention for climate change around the world: A comparative analysis of newspaper coverage in 27 countries. Global Environmental Change, 23(5), 1233-1248.

Stats, S. G. (2017). StatCounter Global Stats.

Van Belle, D. A. (2000). New York Times and network TV news coverage of foreign disasters: The significance of the insignificant variables. Journalism \& Mass Communication Quarterly, 77(1), 50-70.

WCD - World Christian Database (2017) Country / Religion Database. [Online]. Available: http://www.worldchristiandatabase.org/wcd/ [Accessed: 2017 October]. 